\title{
Occupy Online:
}

\section{Facebook and the Spread of Occupy Wall Street}

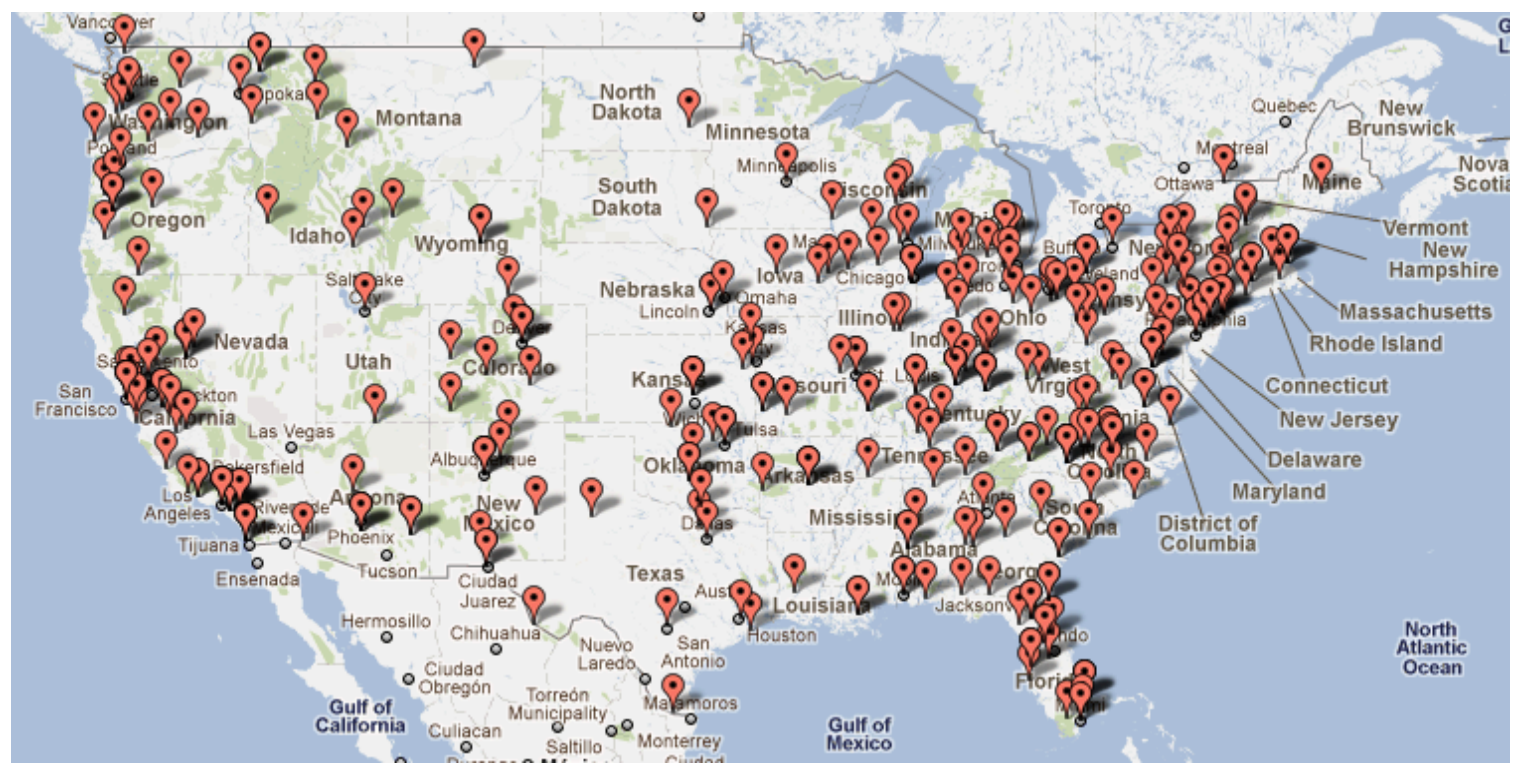

Neal Caren

neal.caren@unc.edu

Sarah Gaby

sgaby@unc.edu

University of North Carolina, Chapel Hill

October 24, 2011 


\section{Occupy Online: \\ Facebook and the Spread of Occupy Wall Street}

\section{Summary}

Since Occupy Wall Street began in New York City on September 17th, the movement has spread offline to hundreds of locations around the globe. Social networking sites have been critical for linking potential supporters and distributing information. In addition to Facebook pages on the Wall Street Occupation, more than 400 unique pages have been established in order to spread the movement across the US, including at least one page in each of the 50 states. These Facebook pages facilitate the creation of local encampments and the organization of protests and marches to oppose the existing economic and political system.

Based on data acquired from Facebook, we find that Occupy groups have recruited over 170,000 active Facebook users and more than 1.4 million "likes" in support of Occupations. By October 22, Facebook pages related to the Wall Street Occupation had accumulated more than 390,000 "likes", while almost twice that number, more than 770,000, have been expressed for the 324 local sites. Most new Occupation pages were started between September 23th and October 5th. On October 11th, occupy activity on Facebook peaked with 73,812 posts and comments to an occupy page in a day. By October 22nd, there had been 1,170,626 total posts or comments associated with Occupation pages. The density of Facebook activism is highest in college towns and in state capitals. Major uses for Facebook within the movement include the recruitment of people and resources to local occupations; information sharing and story telling; and across-group exchanges. While the focus of Occupy Wall Street is on mobilizing individual's offline, online activities greatly facilitate these efforts. 


\section{Occupy Wall Street - Overview ${ }^{1}$}

On July 13, 2011, Adbusters, a Canadian not-for-profit magazine, asked, "Are you ready for a Tahrir moment? On Sept. 17, flood into lower Manhattan, set up tents, kitchens, peaceful barricades and occupy Wall Street." Tactically, the movement drew inspiration from both the Arab Spring and the anti-globalization movement. Adbusters pointed the finger at the "greatest corrupter of our democracy; Wall Street, the financial Gomorrah of America."2 On August 8, just shy of one month after Adbusters launched the campaign, a Facebook page for Occupy Wall Street was established. The first actions on the Facebook page called supporters to a general assembly (GA), a tactical form of participatory democracy that would be one of the signature elements of local Occupations. The New York General Assembly describes itself as the following: “...an open, participatory and horizontally organized process through which we are building the capacity to constitute ourselves in public as autonomous collective forces within and against the constant crises of our times." 3

On September 17th, hundreds of activists gathered in lower Manhattan. The movement received little national coverage until September 24th, when YouTube footage of a protester being pepper sprayed by a New York City police officer went viral. The movement became an even larger media presence with the arrest of more than 700 people on the Brooklyn Bridge on October 1st, following a large rally and march. Organizations such as Occupy Together and Occupy Colleges were formed to spread the movement nationally.

The movement is made unique by its sustained visibility. In cities and towns across the United States, and internationally, groups are setting up organizing rallies and establishing encampments. In some locations, these consist of tents, food stations, and entire outdoor communities dedicated to remaining in "occupation" of a given location. In other cities, encampments may be groups of individuals who, limited by the rules and laws in their towns or cities sleep on sidewalks, sit in grassy areas, or even stand in groups all night. Banners, signs, and printed material often make the groups move visible.

Although the movement began on Wall Street with a focus on the financial sector, the lack of specific demands enabled local movements to adopt messages personalized to their experience or location beyond the focal Wall Street, with the movement being framed as belonging to all those outside of the top $1 \%$ of wealth holders in the United States, as made clear by the dominant movement slogan, "We are the 99\%." This flexible frame, broad identity, and the availability of replicable tactics such as general assemblies and encampments have added to the spread of the Occupy movement.

\section{The Occupy Movement Online}

OWS is primarily an off-line activity. Activists come together in central city locations for hours or days. Decision-making happens here in regularly scheduled general assembly meetings. This face-to-face participatory democracy embodies one of the core values of the movement. Notwithstanding, OWS has been an active presence on major social media platforms using sites such as Facebook, Twitter, Youtube, Meetup, Livestream and individual websites. Our analysis suggests that Facebook is the most prominent social

\footnotetext{
${ }^{1}$ Map on front page created at http://batchgeo.com/

${ }^{2}$ http://www.adbusters.org/blogs/adbusters-blog/occupywallstreet.html 3http://www.nycga.net/about/
} 
networking site associated with the movement. For instance, while occupytogether.org has 13,868, "occupiers," the Facebook page for occupy Boston has 28,020 likes alone. The number of followers on Facebook also far outnumber that on twitter, with only 17,760 twitter followers subscribed to the occupy Boston twitter feed, and 5 Meetup members. The largest of the Meetups, Denver, had 227 occupiers, which is fewer than 7\% of the number of people who used the Occupy Denver Facebook page. Many movement groups also have websites, such as occupyboston.com and occupychi.org.

Occupy Wall Street Twitter usage appears heavily driven by ongoing events. According to usage data from Trendistic, as shown in Figure 1, the periods of heaviest usage of the two most common hashtags associated with OWS, \#OWS and \#Occupywallstreet, peaked on October 1st, when over 700 individuals were arrested on the Brooklyn Bridge, and on October 15th, when hundreds of protests were held around the globe, including a party in New York's Times Square.

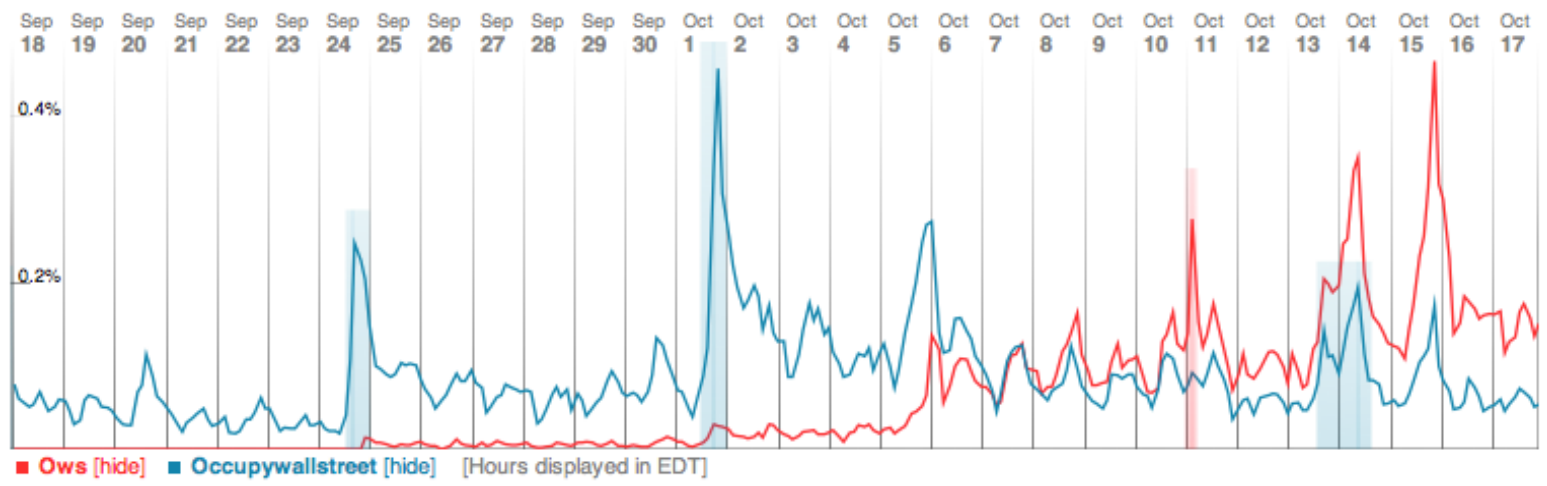

Figure 1. Twitter trends in national Occupy hashtags, based on data from Trendistic.

Trends in Twitter hashtags for local OWS groups show even greater swings. Usage of these hashtags is strongly associated with police-protester interactions, such as the arrest of more than a hundred at the Occupy Boston encampment on the evening of October 10th and the arrest of 23 people at the Occupy Denver encampment on October 14th. Like the movement's first national Twitter spike, on September 24th, associated with New York City police officers using pepper spray, these dramatic, newsworthy events often involve compelling video footage, which can be easily linked to in a tweet. Tweets are fleeting, and the Twitter interface is designed to highlight current news rather than static information. As such, Twitter can be critical for helping a movement during events and to spread word quickly and widely, but is unlikely to be the only web presence for a sustained movement, such as OWS.

\section{Occupying Facebook}

Media accounts have emphasized the role of Facebook in the Occupy movement ${ }^{4}$, and a survey of visitors to occupywallstreet.org found that it was the social networking site most used by protesters 5 . In order to explore the extent and type of Occupy group usage on Facebook, we created a list of all Facebook pages related to the movement. Using published lists $^{6}$ and Facebook searches for key terms, we identified 408 pages on US Occupations. We

\footnotetext{
${ }^{4}$ http://www.wired.com/dangerroom/2011/10/egypt-occupy-wall-street/ 5http://www.fastcompany.com/1789018/occupy-wall-street-demographics-statistics ${ }^{6}$ http://www.dailykos.com/story/2011/10/04/1022722/-Occupy-Wall-Street:-List-and-map-of-over-200US-solidarity-events-and-Facebook\%C2\%A0pages; http://www.collectivedisorder.com/occupytogether/latest
} 
categorized each of the pages based on one of four areas of focus: the Wall Street Occupation (e.g. Occupy Wall St.); efforts to symbolically occupy national institutions (e.g. Occupy the Media) or spread Occupy Wall Street nationally (e.g. Occupy Together); state or regional Occupy coordination pages (e.g. Occupy Florida); or pages on specific local occupations (e.g. Occupy Denver). We identified 13 Wall Street pages; 38 national pages; 33 state or regional pages; and 324 local pages. There are likely to be smaller pages that we did not account for ${ }^{7}$ and we were not able to collect all comments on 19 posts, each of which had more than 500 comments.

For each page, we downloaded all posts and comments that had been made on the page between the day that the page was created and October 22nd, 2011. From this we are able to identify the number of likes for each post and the number, text, content and author of each post and post comment. We are therefore able to identify the amount of activity on each page, and cumulatively, by summing the number of posts and comments. We are also able to identify the cumulative number of users posting across Occupy pages, including the date of their first posting on any Occupy page.

Only data from public Occupy pages were used in this study. The majority of Facebook activity happens on personal pages, and we are not able to observe this information because of privacy restrictions. For example, if an individual posted a status update that she was attending an Occupy Durham event, we would not be able to capture that activity. If she posted this on the Occupy Durham page, however, we would have collected the information. Thus, the estimates that we provide here underestimate the extent to which Facebook users have been engaged with the Occupy Wall Street movement.

More than 400 US Occupation related Facebook pages have been established. Table 1 identifies the top 50 pages based on the number of individuals who had either posted or commented on the page. The largest of these is the page associated with the original Wall Street Occupation. The first posts on this page date to August 8th, and since then, 266,044 people have "liked" the page, with more than 44,000 individuals contributing over 253,000 posts or comments. The second largest page in terms of likes and users is Occupy Together, associated with an effort to spread the occupation tactic across the country. This group encourages users to join or start local occupations using meetup.com, and as of October 19th, the meetup.com/occupytogether/ had 15,942 registered occupiers in 1,996 cities across the globe.

Of the 50 largest Facebook pages in terms of users, 40 of them are associated with specific local occupations. The largest of the local Occupy Facebook pages, in terms of users, was Occupy Boston, with more than 9,000 users, followed by Los Angeles, Philadelphia, and Seattle, and a total of 42 local pages have more than 1,000 users by October 22nd.

${ }^{7}$ Please contact the first author at neal.caren@unc.edu if you know of any pages that we overlooked. 


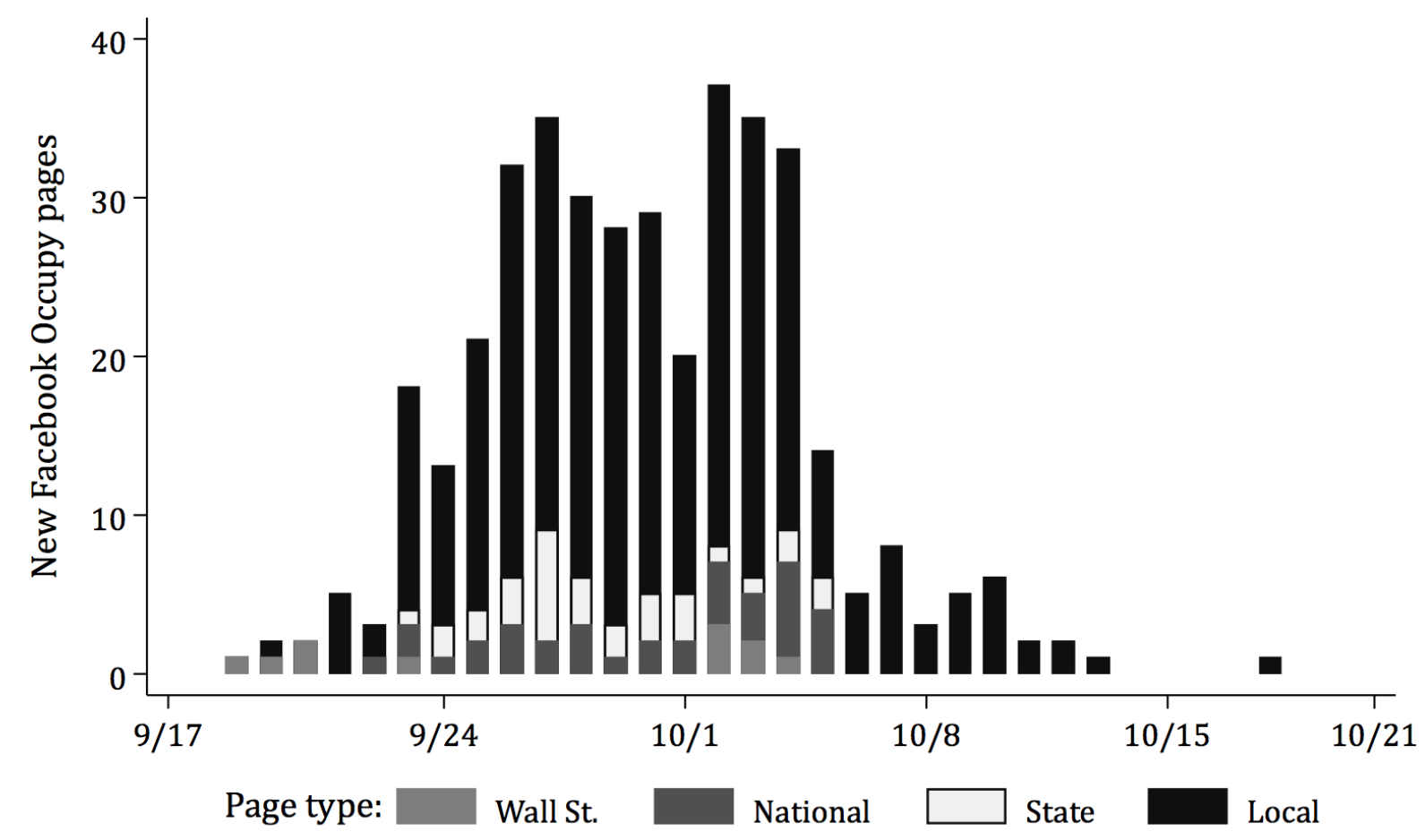

Note: Based on data from 408 Facebook Occupy pages, 9/13-10/21, 2011.

Figure 2. New Facebook Occupy pages created prior to October 20th.

Most new Occupation pages were started between September 23th and October 5th. As shown in Figure 2, only a handful of pages were created in the first few days of the Wall Street Occupation. This number jumped on September 23rd, a date that doubled the total number of Occupation pages. More than 20 pages were created each day between September 26th and October 4th. Since then less than ten pages per day have been created. The increase in the number of pages during this time period was likely a combination of the efforts of Occupy Together and Occupy Colleges to facilitate local occupations, combined with the increased media attention that the movement received on September 24th and October 1st. The growth in pages was heavily driven by local pages. As show in Figure 2, since September 23rd the majority of new pages each day have been formed to organize, or in support of, local occupations. 


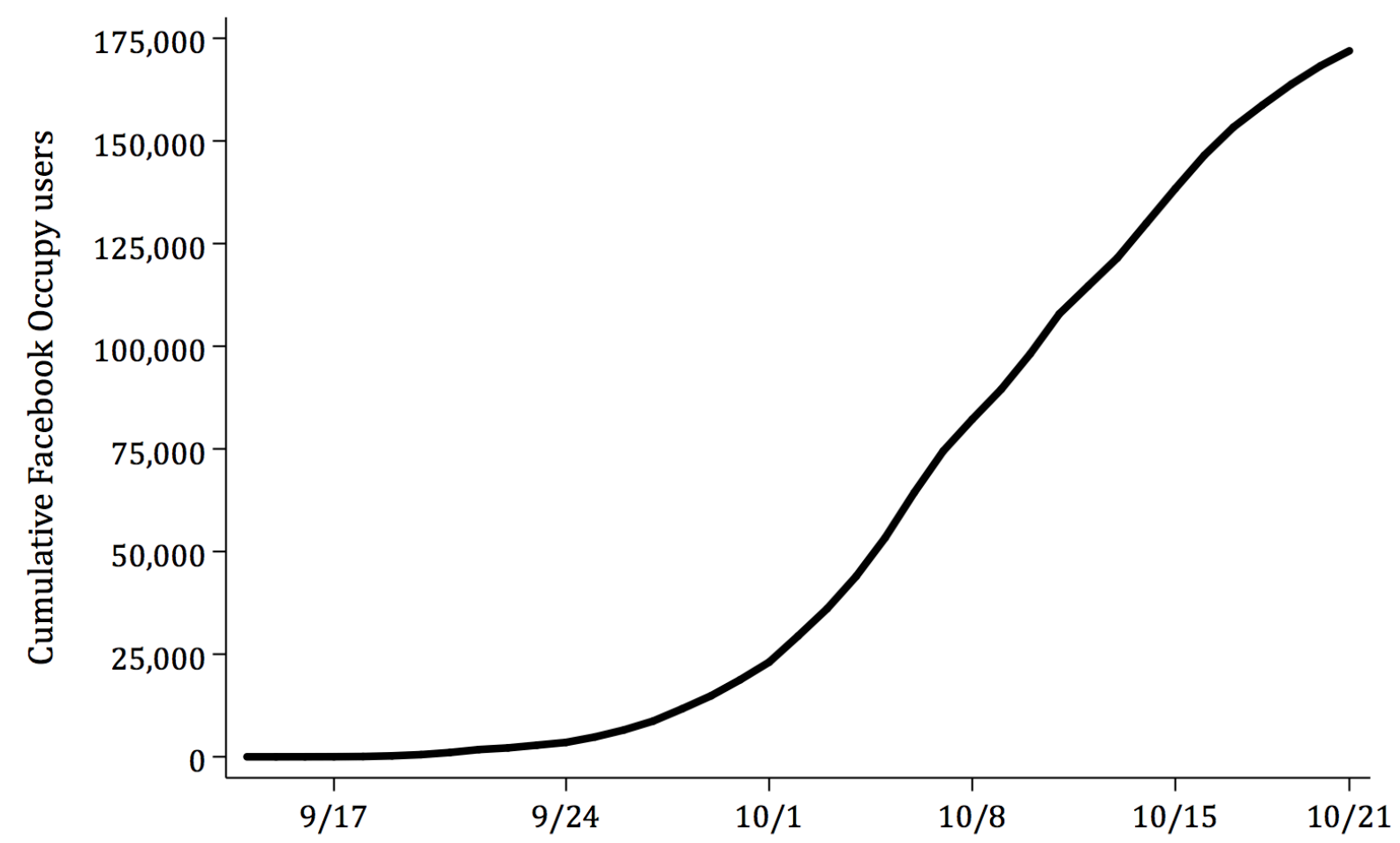

Note: Based on data from 408 Facebook Occupy pages, 9/13-10/21, 2011.

Figure 3. Cumulative number of Facebook Occupy users.

A total of 172,029 people have been active on Occupation related Facebook sites. This number only includes those who have contributed to a page, either by posting or through a comment, and does not include those who have only "liked" or "shared" a page or post. This includes 61,706 individuals active on Occupy Wall Street related pages; 25,866 on national pages; 6,768 on state or regional pages, and 113,901 on local pages. This totals to more than 172,029 individuals since people can be active on more than one type of page.

Most people started becoming active on local pages. Of the people involved in local pages, only $7 \%$ first posted on a Wall Street page, while 3\% first posted on a national or state page. Thus $90 \%$ of individuals who became interested enough in a local Occupation to comment on it first became involved in their local sites. While they are likely to have received information about the Wall Street Occupation first, the vast majority became active through their local site. However, of the 61,706 individuals active on the Wall Street Occupations pages, about $13 \%$ of them were also active on local Occupation sites. Some of this is likely because the Wall Street Occupation is their local occupation, or because they live in an area without any local occupation and are not interested in starting one. 


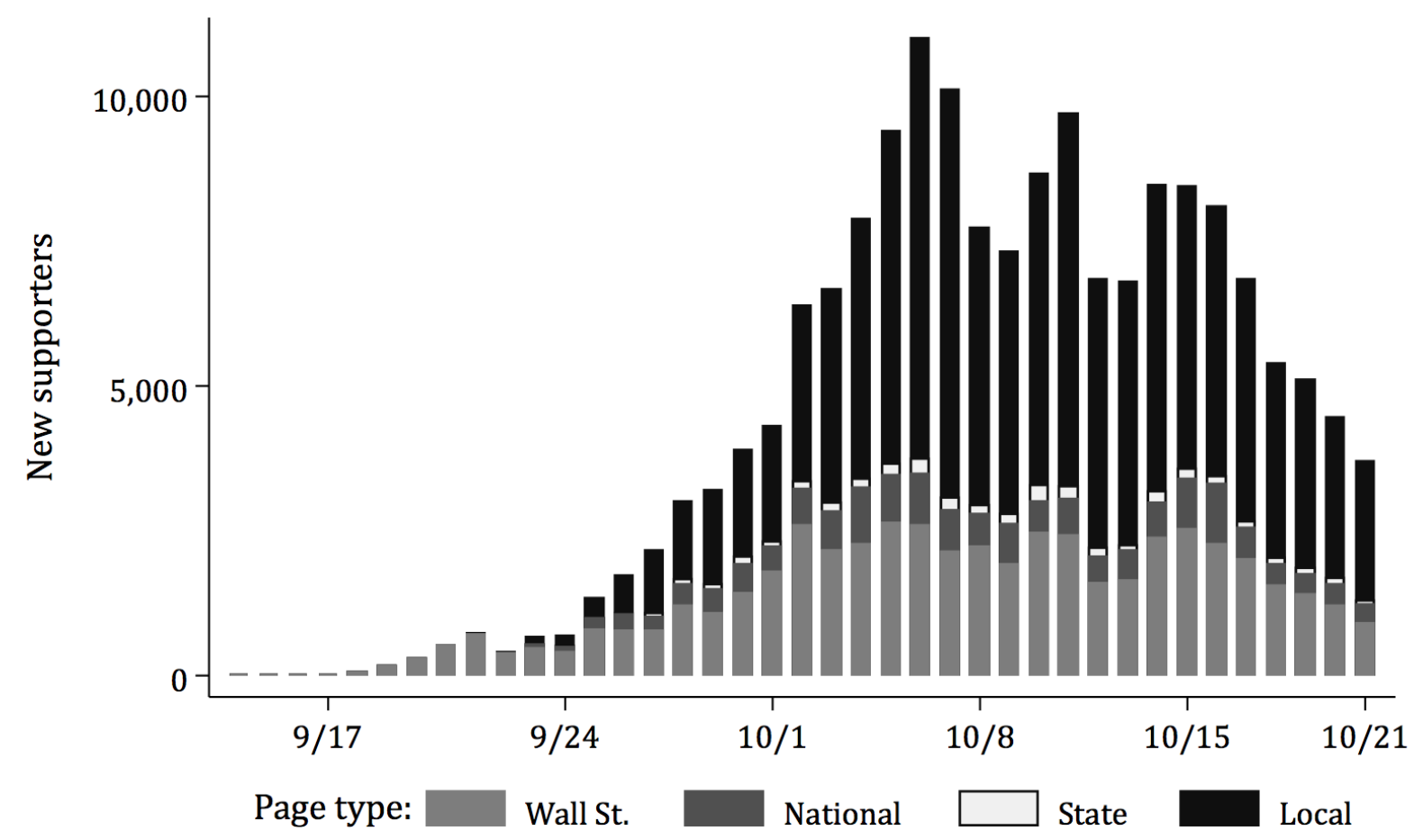

Note: Based on data from 408 Facebook Occupy pages, 9/13-10/21, 2011.

Figure 4. New Facebook Occupy page supporter activity

New users on Facebook grew rapidly between September 24th and October 6th. Prior to that date, there were less than 500 people commenting for the first time on Occupy pages, almost entirely on pages related to the Wall Street Occupation. Starting on $9 / 24$, the number of new users increased everyday, to more than 10,000 on October 6 th. Between October $6^{\text {th }}$ and October $15^{\text {th }}$, a relatively stable average of approximately 7,500 new users have been active on Occupation pages. But, since then, the daily rate of new supporters joining a Facebook Occupy page has declined.

Since September 28th, the majority of new users were active on local pages. Prior to that date, the majority of new users engaged with the movement through sites focused on Occupy Wall Street. Between September 28th and October 2nd, both categories increased at roughly the same rate. Since then, the number of new participants in local sites has been slightly more than twice that of the Wall Street sites.

The number of Facebook Occupiers is approaching the number of online Tea Party activists. According to a report by the Institute for Research and Education on Human Rights (IREHR), there are 321,921 people who have registered their support for the Tea Party across multiple websites ${ }^{8}$. We identified roughly half that number of people active on Facebook in support of Occupations, but four times as many likes. The numbers are not exactly comparable, however. The IHER data was collected after the Tea Party had been active for more than a year; they included multiple websites, and their measure was based 
on individuals signing up, rather than just expressing an opinion on a page. Still, based on the current stable rate of increase in new Occupy users, we estimate that the numbers will be comparable by late November.

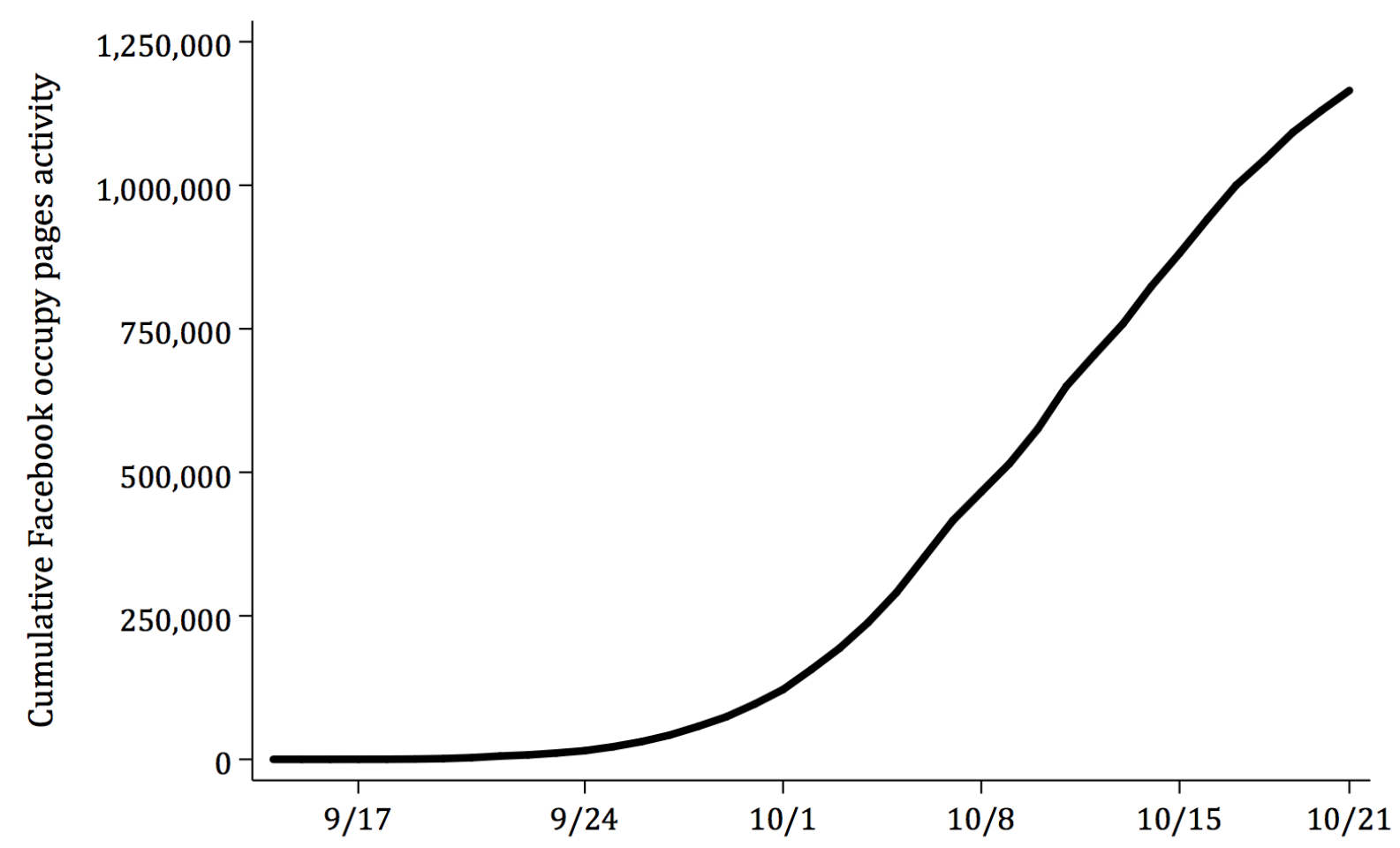

Note: Based on data from 408 Facebook Occupy pages, 9/13-10/21, 2011.

Figure 5. Cumulative posts and comments on Facebook Occupy pages.

By October 22nd, a total of 1,165,274 posts or comments had been contributed to occupy related Facebook pages. The extent of Facebook activity has been vast as is evidenced by the number of posts and comments as well as likes that have occurred across the Occupation related pages. The occupy movement surpassed the 1,000,000 comment mark on October $17^{\text {th }}$. 


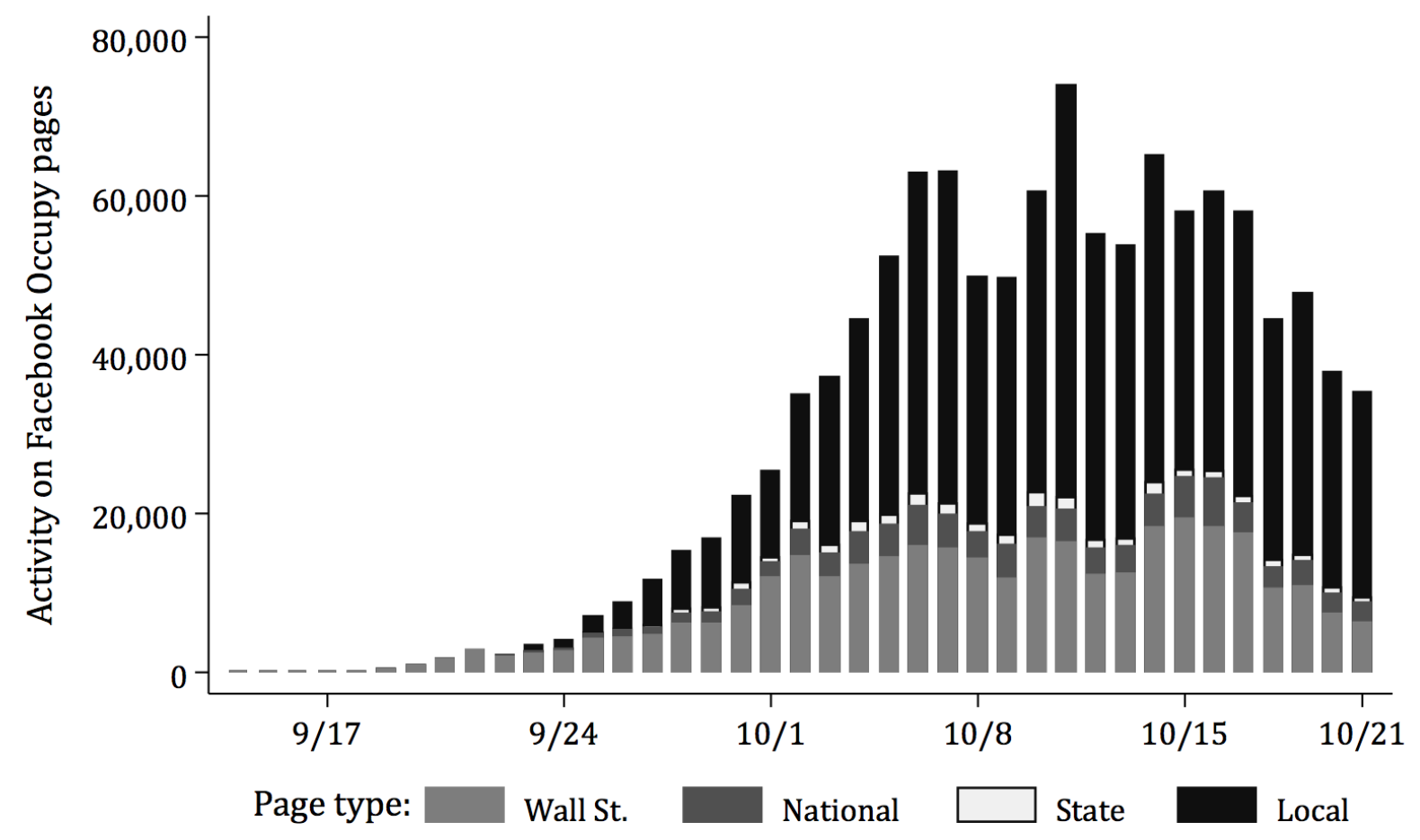

Note: Based on data from 408 Facebook Occupy pages, 9/13-10/21, 2011.

Figure 6. Cumulative posts and comments on Facebook Occupy pages by day.

Total Occupy activity on Facebook peaked on October 11 th with 73,812 posts. On the day when 129 people associated with Occupy Boston were arrested, 21,030 people contributed to 73,812 posts or comments on 352 0ccupy related pages. Similar to new participation patterns, activity on Facebook Occupy pages increased every day between September 22nd and October 8th. Since that day, there has been an average of approximately 50,000 posts or comments per day. Similar to patterns in new membership during this period, $66 \%$ of this activity has happened on local pages, $25 \%$ on Occupy Wall Street pages, with the remainder happening on national or state pages.

Every state has at least some presence, but online participation is lowest in the South. Table 2 ranks each state by the number of participants per 100,000 residents, with Massachusetts and Washington ranked 1 and 2.

The density of Facebook activism is highest in college towns. Ranked by the number of people who have posted on local Facebook Occupation pages as a proportion of the population, college towns are very well represented. The top 10 include the homes of University of Iowa (Iowa City, IA at \#3), the University of Wisconsin (Madison, WI at \#4); Appalachian State University (Boone, NC at \#5); University of California at Santa Cruz (Santa Cruz, CA at \#6); Southern Illinois University (Carbondale, IL at \#7); the University of Missouri (Columbia, MO at \#9); and University of Binghamton (Binghamton, NC at \#8). State capitals, such as Augusta, ME (\#1); Santa Fe, NM (\#3); and Madison, WI (\#4) are also well represented, as seen in Table 3 (see page 17). 
When an occupation page was established for a city is strongly related to the population size of the metropolitan area. Median size for the 29 cities with Facebook Occupation pages established on or before September 23rd was 3,360,0009. For the 107 local pages founded after that date but before October 1st, average city size was 620,000. And for the 238 cities with pages established after that date but before October 17, median size was 161,603.

\section{How Occupy Wall Street Uses Facebook}

So, what are more than 170,000 users doing across more than 400 Facebook pages? Through an analysis of a random sample of pages, we identify five general types of activities that occur on Facebook: recruitment of members, sharing news stories, requests for resources, reaction, and re-posting.

Facebook is a recruiting tool for bringing in new supporters and getting people to events. Recruitment of members is likely the most common activity on occupy group pages. Although not true of all events announcements, even most event-related posts typically end with "who will be there?" or "Be there! Occupy Together!" or other similar sentiments. Member recruitment takes the form of pleas to bring out more supporters, offers for carpooling to sites, requests to contact government officials, and sharing information of where supporters should go, often containing an emotional component (e.g. Ground Update: Central camp has been evacuated and the final structures have come down. There were a few arrests of those defending our kitchen. Occupiers have been pushed out to the perimeters of Lincoln park and yet... Occupy Denver lives on. This is NOT over. Make signs. Come down. Fear Not. OCCUPY!10). More straightforward recruitment attempts take the form of statements such as "Be there or be BORING!11" or "Fresh faces would be nice tonight! 12" Recruitment requests often come with a set of guidelines such as "So location right now is still at the Morris, tents were allowed but only to store and protect personal effects. Sleeping in them is not allowed. Come out and show your support, maybe some hot coffee and donuts in the morning!13"

Facebook is a medium for compiling and sharing relevant news stories. Occupations are constantly sharing news stories in their occupy pages. These stories may be representations of their own group portrayed in the media locally or nationally, and often include articles that reference an exchange between movement members and external institutions, such as the government or police. Posts may proudly proclaim the recognition of the group in the media or the growth of the movement as represented by the media attention. These news stories frequently receive many likes and comments and are often shared across occupy group pages. Posts may also be critical of media coverage. An image that was posted on multiple occupy pages and which received the highest number of comments on the Occupy Wall St. page has the text, "It only takes 20 minutes to shift the blame," and a screen grab comparing sentences from two versions of a New York Times story about the October $1^{\text {st }}$ arrests on the Brooklyn Bridge. ${ }^{14}$ In the first version, the

\footnotetext{
${ }^{9}$ Average city size is based on the median population for each metropolitan area, based on the 2010 Census 10https://www.facebook.com/occupydenver/posts/114564381986455

11https://www.facebook.com/event.php?eid=225971990797431

12https://www.facebook.com/occupydenver/posts/108823505893876

13https://www.facebook.com/OccupySouthBend

${ }^{14}$ http://www.facebook.com/184749301592842/posts/286107748083800
} 
highlighted text reads, "After allowing them onto the bridge, the police cut off and arrested dozens of Occupy Wall Street demonstrators," while the revised versions reads, "In a tense showdown over the East River, police arrested hundreds of Occupy Wall Street demonstrators after they marched onto the bridge's Brooklyn-bound roadway." Commenters used this as an opportunity to express their suspicion of both the media, the police, and the legal system.

Requests for resources can reach a large range of members when posted on Facebook. Since Facebook posts reach a large audience, they often serve as a place to request resources for the movement. It is more likely that someone on the Facebook page will be able to come down to the site to answer this request, for instance; "VERY IMPORTANT UPDATE: We have someone at Westlake who needs insulin as soon as possible. If anyone can get ahold of insulin to donate to the Occupy Seattle movement at Westlake Park please come down and do so. ${ }^{15}$ " It is the users who are not currently at the site who have the ability to bring resources required by the group. Most commonly, these requests focus on basic needs: "Urgent: We really need tarps, tents, and sleeping bags. It's going to rain soon and we're low. Thank you16!" or even requests for non-material basic movement resources such as "If you have a proposal for encampment locations in Durham, please share them on the forum. ${ }^{17}$ " While most requests for resources are for tents, sleeping bags, food, or other encampment support, other requests can provide additional information about a group's structure or focus (e.g. "If anyone has any books/pamphlets/etc. on relevant topics, please consider donating them to the OccupyDC K St library that's been set up for the sake of our collective education!18").

Facebook is a space used for telling narratives or retelling the experiences of other movement participants. General reactions are posted often taking the form of narratives of involvement or the retelling of movement related experiences. Stories are generally targeted to the local group but may have a more general reach. Before telling her narrative, one poster begins "I hope you all don't mind me sharing my story as one of the $99 \%$." This indicates that movement members should be receptive to the telling of narratives. Personal narratives are complemented by the retelling of experiences of other groups, sometimes through digital outlets such as YouTube videos. Commonly posted content deals with cases of violence at occupy sites, such as the October 5th Occupy Wall Street violence. Other reactions deal with combating misconceptions about the group. Some even react to group dynamics by laying out norms of involvement such as a posting on the goals of "consensus decision-making."

For instance, the most commented post on any Occupy Facebook page is below. It is a photo, which shows an elderly man holding a typed piece of paper that reads,

As a young man I served honorably in the Navy. In the 40 years since, I have been a teacher. Now I am retired. Wealth was never a priority - I did expect a decent retirement income and health care and I believe I saved for it with deductions from every payroll check. I raised 3 children. Now, I live in an apartment with my working

\footnotetext{
15 https://www.facebook.com/OccupySeattle/posts/260769550632445

16 https://www.facebook.com/OccupyBoston/posts/186418441436781

17 https://www.facebook.com/occupydurham?ref=ts

18 https://www.facebook.com/OccupyDC/posts/286753244686350
} 
daughter and grandson. My retirement doesn't always cover all of my share of the monthly bills.

I want decent paying jobs for my daughter and the youngsters I educated. I want a decent education for my grandson.

And I am sick of providing welfare to multinationals and being forced to pay for insurance that doesn't insure, food that doesn't nourish and taxes that support arms, oil and drug cartels. I am sick of politians [sic] loyal to Wall Street.

I am part of the $99 \%$

The picture, originally posted to the wearethe99percent tumbler page on October 6th ${ }^{19}$, was liked by 21,920 people, shared by 10,118 people and commented on by 2,192 people after it was posted to the Occupy New Brunswick wall on October 8th. ${ }^{20}$

Facebook provides a medium for instant communication between geographically separated groups within the movement. Correspondence across occupy group pages and between individuals within a group is often facilitated through the reposting of the sorts of materials describe above. Individuals may repost to their Facebook friend list, occupy groups may repost from other occupy pages, and reposting may occur in the form of summoning another group's name as a link to their page with information on something going on in that area or messages to that group. These reposts can serve to spread information such as "I found this on the occupy charlotte Facebook page ${ }^{21}$ " with a link to a news story. They may also serve as requests for or statements of support of a group or the movement generally such as prefaced by "Oh THIS is what democracy looks like 22 " or a posting to the Occupy Boston page to keep on going despite the arrival of police and arrests. Five of the top 10 most commented on posts involve reports of impeding police action. The extent of reposting indicates exchanges of resources between groups within the movement and a general recognition of the national scale of the movement.

Facebook group pages are open to any user posting. Since any registered Facebook user can access the Facebook occupy group pages, there is a wide range of additional activity on Facebook that does not fit within these categories. For instance, sharing your favorite music video or offering it as an anthem of support occurs on pages. Posting of pictures, often flyers for a group or photos taken on location also occur on most pages. Some groups also post messages thanking supporters such as "Sending out a huge THANK YOU to the Veterans for Peace who were on the front line at Occupy Boston tonight! Your strength and courage has inspired us tremendously as we continue this fight! We love you!23" Other times individuals post to pages asking for information like event location or why a Facebook post or group has gone missing. Some groups also post exclamations about their current level of support (e.g. "18,000 likes and growing!24"). The ability of Facebook to host pages that allow for all these sorts of activities is one of the many reasons the Occupy movement has been so active on Facebook.

\footnotetext{
19 http://wearethe99percent.tumblr.com/post/11122693847/as-a-young-man-i-served-honorably-in-thenavy-in 


\section{Conclusion}

This analysis has highlighted the growth of Facebook activity related to Occupy Wall Street. On Facebook, the Occupy movement has attracted more than 170,000 participants across more than 400 pages. Most of these pages were formed during the second and third weeks of the Wall Street Occupation. The number of new participants on these pages increased daily through the third week of the Occupation, and has been relatively stable since then, with no signs of a decline in this form of recruitment. At least one local Occupy site has been formed in every state, but rates of participation are highest outside of the South, in college towns, and in state capitals.

While the pace of new membership and activity is declining on Facebook for the Occupy movement, this may not reflect or foreshadow a decline in the overal movement. Facebook is potentially less relevant to the Occupy movement than to other movements, and is likely to become less relevant as the movement develops. While Facebook has assisted the movement in growing nationally, the presence of round-the-clock encampments in many cities means that there is always an opportunity for physical participation. This is in contrast to many other movements, such as the Tea Party, which only has occasional events. More critically, the movement's emphasis on participatory democracy, embodied in local General Assemblies, privileges face-to-face contact. This provides a unique formal mechanism for new people to become actively involved in the movement. Additionally, local movements are increasingly developing their own websites to facilitate local Occupations. These are distinct from the Facebook ecosystem, which makes it harder to share information with potential supporters, but provides more flexibility in the types of online activities that local movements can offer. Local movement sites have the added advantage of not being associated with a large corporation, which many activists are wary of. That said, Facebook is likely to continue to play a key role in transitioning potential and casual supporters into movement activities, online and offline. 
Table 1. Top 50 Facebook Occupy pages by number of users

\begin{tabular}{|c|c|c|c|c|c|}
\hline Name & Type & Likes & Activity & $\begin{array}{l}\text { Earliest } \\
\text { Date }\end{array}$ & Users \\
\hline Occupy Wall St. & Wall Street & 266,044 & 256,800 & $8 / 8$ & 44,894 \\
\hline Occupy Together & National & 155,410 & 57,079 & $9 / 23$ & 19,021 \\
\hline Occupy Wall Street & Wall Street & 96,933 & 70,003 & $9 / 19$ & 18,126 \\
\hline Occupy Boston & Local & 33,208 & 31,916 & $9 / 22$ & 9,505 \\
\hline Occupy Los Angeles & Local & 32,267 & 24,843 & $9 / 21$ & 7,740 \\
\hline Occupy Chicago & Local & 28,851 & 16,109 & $9 / 23$ & 5,561 \\
\hline Occupy Seattle & Local & 22,160 & 23,090 & $9 / 23$ & 5,713 \\
\hline Occupy Philadelphia & Local & 21,881 & 34,656 & $9 / 23$ & 6,517 \\
\hline Occupy Denver & Local & 16,829 & 18,351 & $9 / 26$ & 4,126 \\
\hline Occupy San Francisco & Local & 16,266 & 4,642 & $9 / 23$ & 2,303 \\
\hline Occupy Austin & Local & 14,856 & 23,892 & $9 / 24$ & 4,562 \\
\hline Occupy Portland & Local & 14,811 & 6,587 & $9 / 25$ & 2,292 \\
\hline Occupy Mainstream Media & National & 13,942 & 8,720 & $9 / 24$ & 3,258 \\
\hline Occupy Dallas & Local & 13,743 & 18,249 & $9 / 23$ & 3,764 \\
\hline Occupy Miami & Local & 12,205 & 6,833 & $9 / 26$ & 2,291 \\
\hline Occupy Houston & Local & 12,002 & 12,237 & $9 / 23$ & 2,315 \\
\hline Occupy San Diego & Local & 11,665 & 13,953 & $9 / 23$ & 3,405 \\
\hline Occupy Tampa & Local & 10,766 & 13,983 & $9 / 23$ & 2,667 \\
\hline OCCUPY ATLANTA & Local & 10,341 & 9,845 & $9 / 22$ & 2,460 \\
\hline Occupy Wall Street & Wall Street & 10,177 & 2,310 & $10 / 2$ & 914 \\
\hline \#OccupySF & Local & 9,730 & 7,108 & $9 / 23$ & 2,233 \\
\hline Occupy Indianapolis & Local & 8,936 & 12,052 & $9 / 21$ & 2,575 \\
\hline Occupy Orlando & Local & 8,870 & 3,590 & $9 / 25$ & 1,227 \\
\hline \#OccupyPhoenix & Local & 8,866 & 13,010 & $9 / 21$ & 2,590 \\
\hline Occupy Pittsburgh & Local & 8,650 & 5,225 & $9 / 24$ & 1,530 \\
\hline OccupyMN & Local & 8,395 & 5,561 & $9 / 23$ & 1,618 \\
\hline Occupy New Orleans & Local & 8,320 & 4,494 & $9 / 24$ & 1,533 \\
\hline Occupy Florida & Local & 8,267 & 2,430 & $9 / 19$ & 1,098 \\
\hline Occupy Columbus & Local & 8,141 & 5,509 & $9 / 24$ & 1,349 \\
\hline Occupy Madison & Local & 8,125 & 4,983 & $9 / 24$ & 2,038 \\
\hline Occupy Cincinnati & Local & 8,108 & 16,435 & $9 / 25$ & 2,252 \\
\hline Carpool to \#Occupy Wallstreet & Wall Street & 8,067 & 4,234 & $9 / 20$ & 1,542 \\
\hline Occupy The Hood & National & 7,984 & 2,441 & $9 / 26$ & 1,125 \\
\hline Occupy Detroit & Local & 7,761 & 3,906 & $9 / 27$ & 1,271 \\
\hline Occupy Nashville & Local & 7,402 & 4,156 & $9 / 23$ & 1,231 \\
\hline Occupy Michigan & State & 7,349 & 2,331 & $9 / 24$ & 1,008 \\
\hline Occupy Baltimore & Local & 7,258 & 5,121 & $9 / 29$ & 1,743 \\
\hline Occupy DC & Local & 7,065 & 1,609 & $9 / 24$ & 838 \\
\hline Occupy Milwaukee & Local & 6,741 & 5,042 & $9 / 25$ & 1,573 \\
\hline Occupy Buffalo & Local & 6,556 & 3,658 & $9 / 26$ & 1,001 \\
\hline Occupy the Federal Reserve & National & 6,495 & 1,842 & $10 / 4$ & 783 \\
\hline Occupy Richmond & Local & 6,415 & 4,763 & $9 / 26$ & 931 \\
\hline Occupy America & National & 6,257 & 6,347 & $9 / 25$ & 1,975 \\
\hline
\end{tabular}




$\begin{array}{llrrrr}\text { Occupy Providence } & \text { Local } & 6,022 & 6,333 & 9 / 27 & 1,319 \\ \begin{array}{l}\text { Media: how about televising } \\ \text { Occupy Wall Street? }\end{array} & \text { Wall Street } & 5,986 & 4,296 & 9 / 23 & 1,940 \\ \text { Occupy Tulsa } & & & & & \\ \text { OccupySacramento } & \text { Local } & 5,984 & 2,539 & 9 / 23 & 749 \\ \text { Occupy Louisville } & \text { Local } & 5,887 & 19,195 & 9 / 21 & 2,458 \\ \text { Occupy Tucson } & \text { Local } & 5,791 & 2,862 & 9 / 25 & 882 \\ \text { Occupy Las Vegas } & \text { Local } & 5,651 & 7,335 & 9 / 25 & 1,258 \\ & \text { Local } & 5,318 & 3,774 & 9 / 25 & 1,328\end{array}$


Table 2. Facebook Occupation activity by state, by number of participants per 100,000 residents.

\begin{tabular}{|c|c|c|c|c|c|}
\hline State & Likes & Activity & $\begin{array}{r}\text { Earliest } \\
\text { Date }\end{array}$ & Users & $\begin{array}{r}\text { Users per } \\
100,000 \\
\text { Residents }\end{array}$ \\
\hline Massachusetts & 36,388 & 34,295 & $9 / 22$ & 10,150 & 155 \\
\hline Washington & 35,456 & 40,158 & $9 / 23$ & 8,953 & 133 \\
\hline Rhode Island & 6,022 & 6,333 & $9 / 27$ & 1,319 & 125 \\
\hline Maine & 4,714 & 9,903 & $9 / 26$ & 1,520 & 114 \\
\hline Colorado & 21,075 & 24,749 & $9 / 26$ & 5,441 & 110 \\
\hline Oregon & 21,934 & 13,213 & $9 / 25$ & 4,168 & 108 \\
\hline Nebraska & 11,384 & 8,659 & $9 / 23$ & 1,825 & 100 \\
\hline North Dakota & 2,918 & 2,658 & $9 / 30$ & 607 & 90 \\
\hline Wisconsin & 18,944 & 15,447 & $9 / 24$ & 5,054 & 89 \\
\hline Hawaii & 5,644 & 4,105 & $9 / 26$ & 1,186 & 87 \\
\hline Vermont & 1,869 & 2,947 & $9 / 26$ & 513 & 81 \\
\hline Pennsylvania & 40,376 & 50,521 & $9 / 23$ & 10,179 & 80 \\
\hline New Mexico & 7,884 & 7,894 & $9 / 28$ & 1,641 & 79 \\
\hline Florida & 70,478 & 65,325 & $9 / 19$ & 14,345 & 76 \\
\hline California & 124,498 & 100,378 & 2/9 & 26,719 & 72 \\
\hline Arizona & 20,481 & 22,726 & $9 / 21$ & 4,574 & 71 \\
\hline Nevada & 8,307 & 6,376 & $9 / 25$ & 1,891 & 70 \\
\hline Indiana & 17,265 & 22,108 & $9 / 21$ & 4,512 & 69 \\
\hline Idaho & 4,898 & 4,194 & $9 / 29$ & 1,037 & 66 \\
\hline Tennessee & 20,969 & 19,606 & $9 / 23$ & 4,208 & 66 \\
\hline Ohio & 31,194 & 37,259 & $9 / 21$ & 7,100 & 61 \\
\hline Iowa & 7,172 & 8,851 & $9 / 28$ & 1,793 & 59 \\
\hline Montana & 2,812 & 2,064 & $9 / 27$ & 539 & 54 \\
\hline Connecticut & 10,472 & 8,630 & $9 / 25$ & 1,900 & 53 \\
\hline Texas & 50,321 & 64,391 & $9 / 23$ & 12,896 & 51 \\
\hline Illinois & 31,304 & 21,969 & $9 / 23$ & 6,415 & 50 \\
\hline New Hampshire & 2,302 & 2,069 & $9 / 28$ & 646 & 49 \\
\hline Alaska & 1,658 & 1,057 & $10 / 3$ & 345 & 48 \\
\hline North Carolina & 20,194 & 21,109 & $9 / 25$ & 4,481 & 47 \\
\hline Oklahoma & 11,640 & 8,179 & $4 / 12$ & 1,755 & 47 \\
\hline Michigan & 25,479 & 18,524 & $9 / 24$ & 4,541 & 46 \\
\hline Kansas & 4,336 & 5,972 & $9 / 27$ & 1,183 & 41 \\
\hline Kentucky & 10,263 & 6,794 & $9 / 25$ & 1,744 & 40 \\
\hline Alabama & 8,134 & 10,917 & $9 / 26$ & 1,885 & 39 \\
\hline Arkansas & 5,350 & 4,215 & $9 / 26$ & 1,143 & 39 \\
\hline Louisiana & 8,955 & 5,155 & $9 / 24$ & 1,696 & 37 \\
\hline Minnesota & 12,095 & 6,285 & $9 / 23$ & 1,982 & 37 \\
\hline Delaware & 1,325 & 2,862 & $9 / 28$ & 326 & 36 \\
\hline Georgia & 16,210 & 13,856 & $9 / 22$ & 3,317 & 34 \\
\hline
\end{tabular}




\begin{tabular}{|c|c|c|c|c|c|}
\hline Missouri & 10,800 & 11,506 & $9 / 25$ & 2,052 & 34 \\
\hline New Jersey & 8,289 & 8,641 & $9 / 27$ & 2,806 & 32 \\
\hline Maryland & 7,258 & 5,121 & $9 / 29$ & 1,743 & 30 \\
\hline West Virginia & 1,651 & 2,236 & $9 / 30$ & 459 & 25 \\
\hline South Carolina & 5,442 & 4,185 & $9 / 27$ & 1,008 & 22 \\
\hline Utah & 4,204 & 1,066 & $9 / 23$ & 524 & 19 \\
\hline Virginia & 9,346 & 7,022 & $9 / 25$ & 1,496 & 19 \\
\hline Wyoming & 217 & 221 & $10 / 7$ & 57 & 10 \\
\hline Mississippi & 1,160 & 1,540 & $10 / 3$ & 278 & 9 \\
\hline South Dakota & 335 & 177 & $10 / 5$ & 73 & 9 \\
\hline
\end{tabular}


Table 3. Facebook Occupation activity by metropolitan area (top 50), by number of participants per 100,000 residents.

\begin{tabular}{|c|c|c|c|c|c|}
\hline Metro Area & Likes & Activity & $\begin{array}{r}\text { Earliest } \\
\text { date }\end{array}$ & Users & $\begin{array}{r}\text { Users per } \\
100,000 \\
\text { Residents }\end{array}$ \\
\hline Augusta-Waterville, ME & 4,714 & 9,903 & $9 / 26$ & 1,520 & 622 \\
\hline Santa Fe, NM & 2,477 & 1,910 & $9 / 29$ & 532 & 369 \\
\hline Iowa City, IA & 2,180 & 2,619 & $10 / 2$ & 560 & 367 \\
\hline Madison, WI & 8,125 & 4,983 & $9 / 24$ & 2,038 & 358 \\
\hline Boone, NC & 854 & 1,473 & $9 / 30$ & 173 & 339 \\
\hline Santa Cruz-Watsonville, CA & 5,073 & 2,681 & $9 / 26$ & 888 & 338 \\
\hline Carbondale, IL & 842 & 986 & $10 / 3$ & 200 & 332 \\
\hline Binghamton, NY & 4,020 & 2,268 & $9 / 25$ & 794 & 315 \\
\hline Columbia, MO & 2,997 & 3,132 & $9 / 25$ & 501 & 290 \\
\hline Spokane, WA & 5,304 & 6,619 & $9 / 27$ & 1,290 & 274 \\
\hline Taos, NM & 339 & 612 & $10 / 3$ & 90 & 273 \\
\hline Austin-Round Rock, TX & 14,856 & 23,892 & $9 / 24$ & 4,562 & 266 \\
\hline Ithaca, NY & 1,496 & 943 & $9 / 27$ & 248 & 244 \\
\hline Appleton, WI & 2,200 & 2,118 & $9 / 26$ & 514 & 228 \\
\hline Tallahassee, FL & 4,287 & 3,225 & $9 / 26$ & 791 & 215 \\
\hline Bellingham, WA & 2,075 & 2,184 & $9 / 30$ & 424 & 211 \\
\hline Burlington-South Burlington, VT & 1,602 & 2,741 & $9 / 26$ & 437 & 207 \\
\hline Pensacola-Ferry Pass-Brent, FL & 2,770 & 6,733 & $9 / 27$ & 891 & 198 \\
\hline Seattle-Tacoma-Bellevue, WA & 24,854 & 27,654 & $9 / 23$ & 6,491 & 189 \\
\hline Roseburg, OR & 331 & 984 & $10 / 7$ & 189 & 176 \\
\hline Flagstaff, AZ & 1,199 & 874 & $9 / 27$ & 234 & 174 \\
\hline Lawrence, KS & 952 & 577 & $10 / 4$ & 192 & 173 \\
\hline Moscow, ID & 193 & 295 & $10 / 6$ & 63 & 169 \\
\hline Helena, MT & 413 & 709 & $9 / 28$ & 125 & 167 \\
\hline Manchester-Nashua, NH & 2,302 & 2,069 & $9 / 28$ & 646 & 161 \\
\hline Butte-Silver Bow, MT & 191 & 297 & $9 / 27$ & 55 & 161 \\
\hline $\begin{array}{l}\text { Boston-Cambridge-Quincy, MA- } \\
\mathrm{NH}\end{array}$ & 33,335 & 31,918 & $9 / 22$ & 9,507 & 159 \\
\hline Bloomington, IN & 1,331 & 1,026 & $9 / 27$ & 291 & 151 \\
\hline Stillwater, OK & 2,190 & 704 & $9 / 25$ & 231 & 149 \\
\hline Indianapolis-Carmel, IN & 8,936 & 12,052 & $9 / 21$ & 2,575 & 147 \\
\hline Milwaukee-Waukesha, WI & 7,409 & 7,242 & $9 / 25$ & 2,250 & 145 \\
\hline Olympia, WA & 1,991 & 877 & $10 / 1$ & 364 & 144 \\
\hline Караa, HI & 276 & 405 & $10 / 4$ & 95 & 142 \\
\hline Kalamazoo-Portage, MI & 1,476 & 2,703 & $9 / 29$ & 461 & 141 \\
\hline Pocatello, ID & 480 & 734 & $10 / 4$ & 126 & 139 \\
\hline Pueblo, CO & 656 & 1,194 & $10 / 3$ & 221 & 139 \\
\hline Morgantown, WV & 709 & 869 & $10 / 2$ & 174 & 134 \\
\hline Lafayette, IN & 995 & 1,791 & $9 / 29$ & 270 & 134 \\
\hline Redding, CA & 739 & 1,385 & $10 / 3$ & 236 & 133 \\
\hline Fort Wayne, IN & 1,855 & 3,552 & $9 / 29$ & 544 & 131 \\
\hline
\end{tabular}


Eureka-Arcata-Fortuna, CA

Missoula, MT

Grand Rapids-Wyoming, MI

Raleigh-Cary, NC

Rutland, VT

Reno-Sparks, NV

Ann Arbor, MI

Fargo, ND-MN

Sacramento, CA

Bend, OR

$\begin{array}{rrrrr}1,797 & 1,117 & 9 / 28 & 344 & 128 \\ 929 & 455 & 10 / 2 & 138 & 126 \\ 3,941 & 7,316 & 9 / 30 & 968 & 125 \\ 5,082 & 9,629 & 9 / 27 & 1,407 & 124 \\ 267 & 206 & 10 / 2 & 76 & 123 \\ 2,793 & 2,414 & 9 / 27 & 514 & 121 \\ 2,490 & 1,104 & 9 / 29 & 413 & 120 \\ 946 & 1,502 & 9 / 30 & 248 & 119 \\ 6,315 & 19,402 & 9 / 21 & 2,525 & 117 \\ 889 & 749 & 9 / 27 & 185 & 117\end{array}$

